\title{
SURVIVAL OF VIBRIO CHOLERAE IN TREATED AND UNTREATED RUM DISTILLERY EFFLUENTS
}

\author{
Yazmín A. Rojas and Terry C. Hazen* \\ Microbial Ecology Laboratory, Department of Biology, College of Natural Sciences, University of Puerto \\ Rico, Río Piedras, PR 00931, U.S.A.
}

(First received February 1988; accepted in revised form August 1988)

\begin{abstract}
The effect of treated (methane digestor) and untreated rum distillery effluent on Vibrio cholerae growth and activity was examined in microcosms under a variety of controlled conditions and in diffusion chambers with non-controlled conditions. Temperature and $\mathrm{pH}$ in the microcosms were the most critical parameters influencing bacterial density and metabolism. The high nutrient levels of both types of effluents allowed growth and activity of $V$. cholerae at $\mathrm{pH}$ below 6.6 and at temperatures above $45^{\circ} \mathrm{C}$, conditions that normally invoke the viable but non-culturable state. The generation time of $V$. cholerae in both types of rum distillery effluent was half that reported for other microcosm studies. The growth rates as determined by viable and direct cell counts were always higher in untreated effluents; however, metabolic activity of $V$. cholerae in treated effluents was often higher than in untreated effluents. Under non-controlled conditions (diffusion chambers), $V$. cholerae showed no significant differences in survival or activity between treated and untreated effluents. Competition with other microbes in the effluent may reduce the effect that treatment has on the growth of $V$. cholerae. Survival rates for $V$. cholerae were higher than those reported earlier for ambient waters. Anaerobic digestion of rum distillery effluents alone was insufficient in reducing the potential microbial hazard and rum distillery effluents to tropical environments and/or public health.
\end{abstract}

Key words -rum, distillery, effluent, bacteria, marine, microcosm, vibrio, pathogen, pollution, treatment

\section{INTRODUCTION}

Vibrio cholerae and other vibrios are part of the indigenous microflora of most estuaries (Colwell et al., 1981; Desmarchelier and Reichelt, 1981; Hood et al., 1983; Kaper et al., 1979; Kodama et al., 1984; Lee et al., 1982; West and Lee, 1982). Considering the reports of recent outbreaks of cholera traced to shellfish from warm water environments (Davis and Sizemore, 1982; Desmarchelier and Reichelt, 1982; Kenyon et al., 1984; Motes et al., 1983; Roberts et al., 1982; Rogers et al., 1980; Spira et al., 1981), it has become increasingly important to understand the ecology of these bacteria. Many studies have suggested that $V$. cholerae is incapable of surviving in seawater at salinities of $35 \mathrm{ppt}$, and high temperatures, i.e. $>25^{\circ} \mathrm{C}$ are stressful (Guthrie and Scovill, 1984; Hood and Ness, 1982; Huq et al., 1984; Seidler and Evans, 1984; Singleton et al., 1982a,b; Vasconcelos and Swartz, 1976). However, recent studies have suggested that $V$. cholerae may be able to survive under these conditions or under starvation conditions and yet be unculturable on standard media (Baker et al., 1983; Colwell et al., 1985; Hood et al., 1986; $\mathrm{Xu}$ et al., 1982). It has also been well documented that the survival of $E$. coli can be dramatically decreased by high solar radiation (Fujioka et al., 1981). Since all of these conditions are

* Present address: E. I. du Pont de Nemours \& Company Inc., Savannah River Laboratory, Environmental Sciences Division, Aiken, SC 29808, U.S.A. normal and constant in tropical marine areas like Puerto Rico it was surprising to us that our laboratory (Biamón and Hazen, 1983; Fuentes et al., 1983; López-Torres et al., 1988) and others (Grimes et al., 1984; Hagler and Medonça-Hagler, 1981) were able to isolate $V$. cholerae and $E$. coli from tropical coastal waters. Other work by our group had shown that Aeromonas hydrophila was capable of growing at densities over $10^{7}$ cells $\mathrm{ml}^{-1}$ when diffusion chambers with the bacteria were suspended in marine coastal areas of Puerto Rico contaminated with rum distillery effluent (Biamón and Hazen, 1983; LópezTorres et al., 1988). We also observed that rum distillery effluent served as a chemoattractant to $V$. cholerae (Fuentes et al., 1983).

Until recently, nearly all rum distillers have been pumping untreated effluents directly into coastal waters. One of these recently began an anaerobic methane digestion treatment prior to discharge. We undertook the present study to determine if the treatment process had an effect on the survival and growth of $V$. cholerae using diffusion chambers and microcosms, and to determine which water quality parameters might significantly affect growth and survival of allochthonous bacteria in treated and untreated rum distillery effluents.

\section{Study site}

A rum distillery on the northwest coast of Puerto Rico near Arecibo ( $18^{\circ} 28^{\prime} \mathrm{N}, 66^{\circ} 44^{\prime} \mathrm{W}$ ) was used as the source for untreated rum distillery effluents. The treated effluent 
was obtained from a methane digestor model of the process used by a rum distillery in Puerto Rico. This model was maintained and operated by the Quality Control Laboratory, College of Engineering, University of Puerto Rico, Mayagüez Campus. The digestor is an anaerobic contactor type, with a full capacity of 3.91 . The methanogenic seed bacteria were obtained from sewage. Temperature and $\mathrm{pH}$ are kept steady with daily monitoring, and other parameters, such as BOD and COD are taken regularly.

\section{Water quality}

Temperature was measured using a model 870 digital thermometer (Keithley Instruments, Cleveland, Ohio). The $\mathrm{pH}$ was measured with a $\mathrm{pH}$ meter (model 130, Corning Medical, Medfield, Mass.). Alkalinity and hardness were measured by standard methods (APHA, 1985) using Spectrokits (Bausch and Lomb, Rochester, N.Y.). Salinity and sugar concentrations were measured using hand refractometers (American Optical, Buffalo, N.Y.). BOD and COD measurements were done by the Quality Control Laboratory (UPR, Mayagüez, P.R.) using standard methods (APHA, 1985). Water samples were collected in presterilized, black, polypropylene bottles and preserved by appropriate fixation with sulfuric acid, mercuric chloride or zinc acetate (APHA, 1985). All water samples were transported on ice to the laboratory $(<6 \mathrm{~h})$ and preserved at $4^{\circ} \mathrm{C}$ until analyzed, within 2 weeks of collection. Fixed samples were analyzed in the laboratory for turbidity, chlorophyll $a$, sulfates, nitrates plus nitrites, orthophosphates and total phosphorus (APHA, 1985).

\section{Bacteriological analysis}

Water samples for Vibrio spp were collected by grab sampling, $20 \mathrm{ml}$ were incubated $24 \mathrm{~h}$ at $37^{\circ} \mathrm{C}$ in $80 \mathrm{ml}$ alkaline peptone water. Aliquots from this incubation were diluted $\left(0.5 \mathrm{ml}\right.$ to $\left.10^{-6} \mathrm{ml}\right)$ in sterilized distilled water and filtered through $0.45-\mu \mathrm{m}$-pore-size, 47-mm-dia, HA-type, membrane filters (Millipore Corp., Bedford, Mass.). Filters were placed on thiosulfate-citrate bile-sucrose (TCBS) agar (Difco Laboratories, Detroit, Mich.), and incubated for $24 \mathrm{~h}$ at $37^{\circ} \mathrm{C}$. After incubation, yellow colonies were considered presumptive $V$. cholerae and all colonies growing on TCBS were recorded as total presumptive vibrio counts. The yellow colonies from countable plates were subcultured onto trypticase soy agar (TSA) (BBL, Cockeysville, Md) with $1 \% \mathrm{NaCl}$. After Gram staining, those isolates which were Gram-negative and rod shaped were tested for oxidase (filter paper method), motility (tube method), sensitivity to 2,4-diamino 6,7-diisopropylopteridine phosphate $(0 / 129)$ using $150 \mu \mathrm{g} \mathrm{ml}^{-1}$ discs, lactose oxidation/fermentation (O/F), growth without $\mathrm{NaCl}$ and biochemical properties using the API20-E system (Analytab Products, Plainview, N.Y.). Isolates that were Gram-positive and cocci shaped were tested for catalase, oxygen requirements and hemolysis on blood agar. Those isolates that were chain-like, catalase negative and facultative anaerobic were biochemically identified using the API20-S system (Analytab). The control strains used were $V$. cholerae ATCC 25872 (O. Felsenfeld $280 \mathrm{NAG}$ ) and $V$. cholerae ATCC (NCTC 8021, El Tor biotype). All isolates and control strains were maintained in culture on TSA $1 \% \mathrm{NaCl}$.

Direct $V$. cholerae counting was by indirect fluorescent antibody staining (IFA), according to $\mathrm{Xu}$ et al. (1982). A $1 \mathrm{ml}$ sample was passed through a $0.2-\mu \mathrm{m}$-pore-size, 25-mm-dia, polycarbonate, membrane filter (Nuclepore Corp., Pleasanton, Calif.) prestained with Sudan Black $(1: 15,000)$ for $24 \mathrm{~h}$. $V$. cholerae antiserum poly $(1: 32)$ (Difco) was used as the primary antisera. Rabbit globulin antiglobulin (goat) conjugated with florescein isothiocyanate (1:160) (Difco) was used as the secondary antibody.

\section{Cell activity and total cell count}

Total cell counts were determined by rigorous acridine orange direct count (AODC) as described by López-Torres et al. (1988). Simultaneously the percent of respiring bacteria was measured in terms of the reduction of 2-( $p$-iodophenyl)-3-( $p$-nitrophenyl)-5-phenyl tetrazolium chloride (INT) to INT-formazan, as described by Zimmermann et al. (1978). All techniques are as previously described by our laboratory (Carrillo et al., 1985; LópezTorres et al., 1987, 1988; Valdés-Collazo et al., 1987).

\section{Survival studies}

Microcosms were used to determine the effect controlled environmental parameters have on $V$. cholerae, as described by Singleton et al. (1982a,b). Screw-capped $250 \mathrm{ml}$ flasks were cleaned with $0.025 \mathrm{M}$ potassium dichromate, rinsed 10 times with distilled deionized water and sterilized by autoclaving. The microcosms consisted of $50 \mathrm{ml}$ run effluent, which were brought to appropriate $\mathrm{pH}$, concentration and temperature. Effluent concentrations used were 25,50 and $100 \%$, in filter-sterilized $(0.2 \mu \mathrm{m}$ pore size) sea water ( $35 \mathrm{ppt}$ ); $\mathrm{pH} 4.6,6.6$ and 8.6; incubated at 25,35 and $45^{\circ} \mathrm{C}$. Combinations of the three parameters were made for each rum distillery effluent treatment for a total of 54 different microcosms. Rum distillery effluents were sterilized by membrane filtration and added aseptically to each flask. The strain used for this study was $V$. cholerae ATCC 25872, since most environmental strains belong to the non-01 group (Colwell et al., 1981). The strain was incubated $24 \mathrm{~h}$ at $35^{\circ} \mathrm{C}$ in $100 \mathrm{ml}$ of TSB (Difco). Cells were collected by centrifugation and washed 5 times with a sterile $0.85 \%(w / v)$ saline solution. After the final washing, a stock suspension was prepared in sterile saline and inoculated to microcosms at an initial concentration of $4 \times 10^{2} \mathrm{cells} \mathrm{m}^{-1}$. All microcosms were incubated for 4 days with constant agitation (125 rpm) in a shaker-water bath. Samples were collected daily with sterile $1 \mathrm{ml}$ pipettes. For viable counts microcolonies were counted with the aid of a membrane filter stain. Direct (AODC), and metabolic (INT) counts were done as described above.

Pure cultures of $V$. cholerae (non 01) ATCC 25872 were grown in $T_{1} N_{1}$ broth for $24 \mathrm{~h}$ at $35^{\circ} \mathrm{C}$. The cells were harvested by centrifugation and washed in filter-sterilized PBS (pH 7.0). The number of cells were determined with a Model ZM Coulter Counter (Coulter Electronics, Inc., Hialeah, Fla) and adjusted to $10^{8}$ cells $\mathrm{ml}^{-1}$. The final suspension was placed in a membrane diffusion chamber just prior to immersion at the study site. Chambers were a modification (Biamón and Hazen, 1983; Carrillo et al., 1985; West and Lee, 1982) of the MSU-DME chamber (McFeters and Stuart, 1972). Diffusion surfaces were created by placing $0.2-\mu \mathrm{m}$-pore-size, 142-mm-dia, nylon-reinforced, Versapore membrane filters (Gelman Instrument Co., Ann Arbor, Mich.) on each chamber side. Chambers were suspended just below the surface in half-filled 201 . aquaria containing treated and untreated distillery effluent. One $\mathrm{ml}$ samples were taken from each chamber at regular intervals for $72 \mathrm{~h}$. Half of each sample was fixed with $10 \%$ phosphate-buffered formalin (pH 7.0) and refrigerated for later counting with an Coulter Counter (López-Torres et al., 1988). The other $0.5 \mathrm{ml} \mathrm{sample}$ was incubated with INT for $20 \mathrm{~min}$ at in situ temperature and then fixed with $37 \%$ formaldehyde for futher determination of total direct cell count, percent activity and percent respiring cells as described above.

\section{Data analysis}

The data were analyzed using prepared programs for Apple II, Macintosh, IBM 4321 computers and NIH Prophet Computer system. A multiple factorial analyses of variance were used to test for differences between microcosms and diffusion chambers. The data were made more homoscedastic by $\log$ transformation of parameters as needed. Any statistical probability equal or less than 0.05 was considered significant (Zar, 1984). 
RESULTS

\section{Water quality}

Measurements of water quality parameters were obtained from both untreated and treated rum distillery effluents (Table 1). Values for chlorophyll $a$, orthophosphates, sulfates, total phosphorus and turbidity were lower in raw than in treated mostos, mostos is the Spanish term for rum distillery effluent. pH was always higher in raw mostos. BOD and COD were not detectably different before and after methane digestor treatment.

\section{Bacterial communities}

No viable bacteria were detected from undischarged distillery effluents. The untreated effluent had significantly higher densities of total bacteria than the treated effluent as measured by direct count (Table 1). Total microbial cell activity was not significantly greater in raw effluent than in treated effiuent. No Vibrio spp were isolated from raw or treated effluents. Indirect fluorescent antibody staining of both treated and untreated effluents also did not reveal any Vibrio-like bacteria.

\section{Microcosms}

Culturable bacterial counts were significantly different over time for all of the microcosms ( $F=68.2$, d.f. $=3$ and $24, P<0.0001)$. The highest population density was obtained after $48 \mathrm{~h}$, data from this sampling were used for illustration (Fig. 1). Temperature $(F=293,74.1,21.6$ and 386$)$ and $\mathrm{pH}$ ( $F=76.6,22.712,6$ and 30.6 ) were significant factors influencing population density and metabolic activity (d.f. $=2$ and $24, P<0.0001$ for all cases). Culturable bacterial counts were also significantly influenced by treatment $(F=312$, d.f. $=1$ and $24, P<0.0001)$, higher bacterial densities were always obtained from untreated effluents. Comparisons between temperature and $\mathrm{pH}$ show significant differences in bacterial densities associated with treatment $(F=15.8$, d.f. $=4$ and $24, P<0.0001)$. Culturable bacterial counts increased with temperature up to $35^{\circ} \mathrm{C}$ (Fig. 1). An increasing effect was observed with $\mathrm{pH}$; however, at $35^{\circ} \mathrm{C}$, differences between $\mathrm{pH} 6.6$ and 8.6 were not significant. Colonies growing at 25 and $45^{\circ} \mathrm{C}$ at any $\mathrm{pH}$ did not show characteristic $V$. cholerae appearance. They grew as microcolonies and were difficult to detect and count. Microcosms of different rum effluent concentrations incubated at selected temperatures show significant differences in densities of bacteria associated with treatment level and temperature $(F=72.2$, d.f. $=2$ and $24, P<0.0001)$. The highest densities were seen at $35^{\circ} \mathrm{C}$ with no significant differences due to concentration; however, high temperature combined with raw effluent caused some decrease in bacterial densities as effluent concentration was increased (Fig. 1). Viable bacterial densities in treated effluent decreased with increasing temperature. Colony counts at various $\mathrm{pH}$, incubated

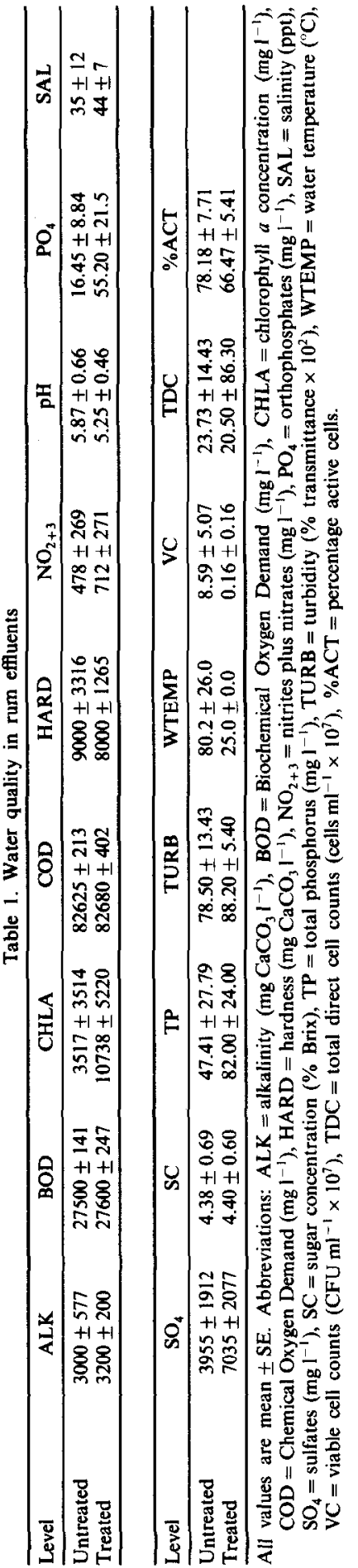



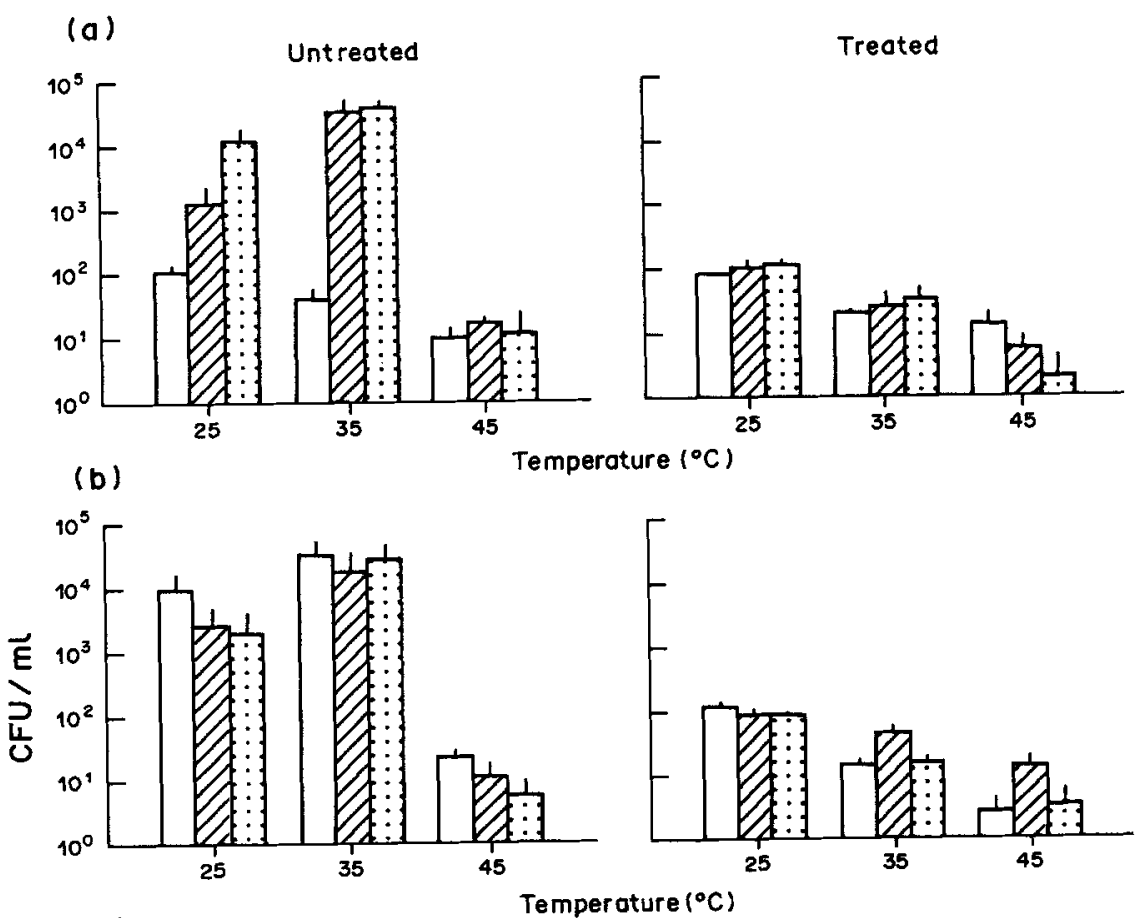

(c)
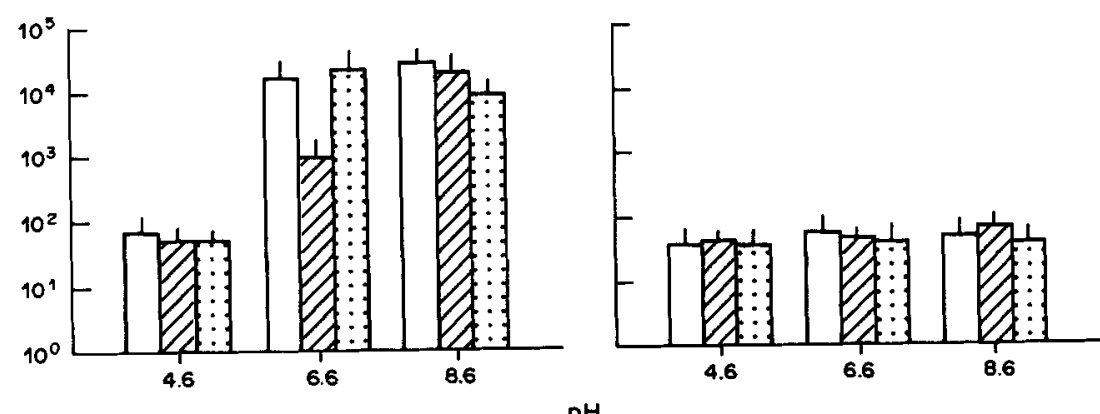

Fig. 1. Densities of Vibrio cholerae ATCC 25872 at various pHs incubated at selected temperatures in untreated and treated rum effluents. [Mean $\pm \mathrm{SE}$ : (a) open bars $=\mathrm{pH} 4.6$; left hatched bars $=\mathrm{pH} 6.6$; dotted bars $=\mathrm{pH} 8.6$; (b) open bars $=25 \%$; left hatched bars $=50 \%$; dotted bars $=100 \%$; (c) open bars $=25 \%$; left hatched bars $=50 \%$; dotted bars $=100 \%$, percent concentration of effluent in filter-sterilized sea water.]

at selected concentrations were also significantly different $(F=3.3$, d.f. $=4$ and $24, P<0.029)$ with remarkable differences between $\mathrm{pH}$ according to the type of effluent treatment $(F=40.2$, d.f. $=2$ and 24 , $P<0.0001)$. The highest $\mathrm{pH}$, for any combination of factors using untreated effluent, always gave the greatest culturable densities of bacteria. No significant differences were seen for any combination of factors when treated effluents were used. Culturable bacterial counts in microcosms which contained untreated effluent were one or two orders of magnitude higher than microcosms with treated effluent, regardless of microcosm incubation conditions.

Total direct bacterial counts were significantly influenced by effluent treatment $(F=116$, d.f. $=1$ and $24, P<0.0001$ ) combined with temperature, $\mathrm{pH}$ and concentration $(F=5.3$, d.f. $=8$ and 24 , $P<0.001$ ) (Fig. 2). Total cell densities showed significant differences in temperature and $\mathrm{pH}$ combined $(F=29.3$, d.f. $=4$ and $24, P<0.0001)$. Also, $\mathrm{pH}$ combined with the type of treatment influenced cell densities significantly $(F=33.6$, d.f. $=2$ and 24 , $P<0.0001)$. The highest direct count densities were observed at $35^{\circ} \mathrm{C}$ (Fig. 2) at $\mathrm{pH} 6.6$ and 8.6. No remarkable differences could be seen at other temperatures or by effluent treatment. Temperature and concentration of the effluent significantly affected total cell densities $(F=3.6$, d.f. $=4$ and 24 , $P<0.019)$ and were related to type of treatment $(F=3.0$, d.f. $=4$ and $24, P<0.04)$. The combined effect of treatment and temperature on total cell density is shown in Fig. $2(F=73.7$, d.f. $=2$ and 24 , $P<0.0001$ ), with higher densities in untreated effluents at $35^{\circ} \mathrm{C}$ and lower concentrations of effluent ( 25 and $50 \%$ ). High temperatures and treated rum effluents showed similar densities. Total cell counts at 

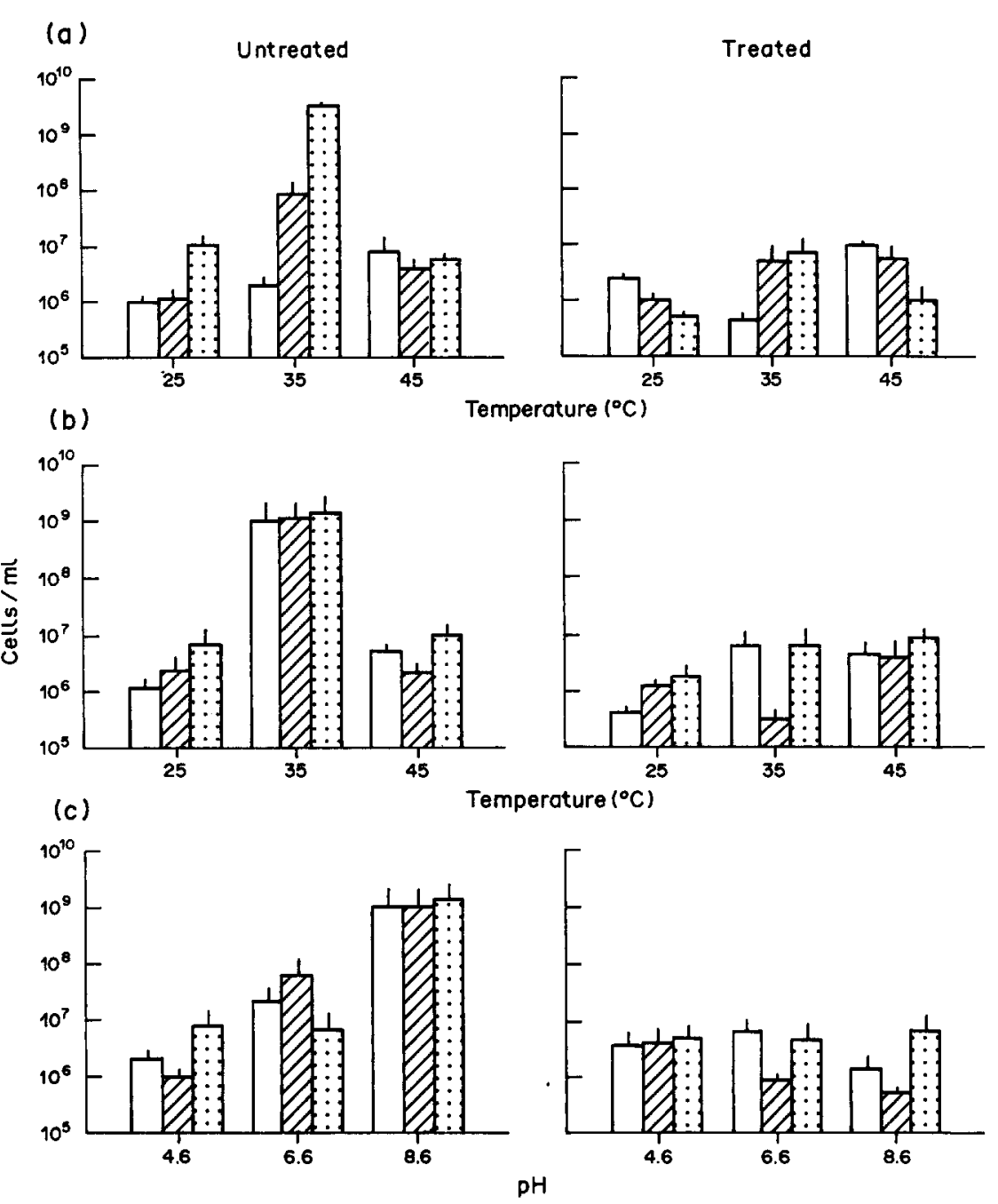

Fig. 2. Total cell counts of Vibrio cholerae ATCC 25872 at various pHs incubated at selected temperatures in untreated and treated rum effluents. [Mean \pm SE: (a) open bars $=\mathrm{pH} 4.6$; left hatched bars $=\mathrm{pH} 6.6$; dotted bars $=\mathrm{pH} 8.6$; (b) open bars $=25 \%$; left hatched bars $=50 \%$; dotted bars $=100 \%$; (c) open bars $=25 \%$; left hatched bars $=50 \%$; dotted bars $=100 \%$, percent concentration of effluent in filter-sterilized sea water.]

various $\mathrm{pH}$, at different concentrations of effluent showed significant combined effect of treatment and $\mathrm{pH}(F=33.6$, d.f. $=2$ and $24, P<0.0001)$ and $\mathrm{pH}$ with concentration of the effluent $(F=6.0$, d.f. $=4$ and $24, P<0.002)$. An increasing effect was observed on total densities directly proportional to $\mathrm{pH}$ in raw effluents (Fig. 2). Similar tendencies were observed in treated effluents with an overall density decrease at intermediate concentrations.

The percent of active cells in the microcosms were influenced by treatment combined with temperature, $\mathrm{pH}$ and concentration in the same way as total cell counts. Significant differences in bacterial activity resulted from combined influence of treatment level, temperature and $\mathrm{pH}(F=4.5$, d.f. $=4$ and 24 , $P<0.007$ ). Specific differences are shown on Fig. 3, as percent activity increases with temperature and $\mathrm{pH}$ $(F=3.5$, d.f. $=4$ and $24, P<0.022)$ in treated effluents. The effect of temperature and concentration was also significant $(F=3.5$, d.f. $=4$ and 24 , $P<0.022$ ). Bacterial cell activity was related to temperature more than concentration or treatment level (Fig. 3). The activity of cells in the microcosms at various $\mathrm{pH}$ at different effluent concentrations was not significantly different. However, some decrease in activity with increasing effluent concentration was observed in treated distillery effluent (Fig. 3).

The percentage of respiring cells (Fig. 4) showed significant differences caused by temperature $(F=386$, d.f. $=2$ and $24, P<0.0001)$ and $\mathrm{pH}$ $(F=30.6$, d.f. $=2$ and $24, P<0.0001)$. Higher respiration with increasing temperature and $\mathrm{pH}$ was observed for untreated effluents (Fig. 4), although only slightly higher respiration rates were observed for treated effluents. The same effect was noted on Fig. 3, illustrating the relationship between temperature and effluent concentration $(F=4.9$, d.f. $=4$ and $24, P<0.005)$. Effluent concentration combined 

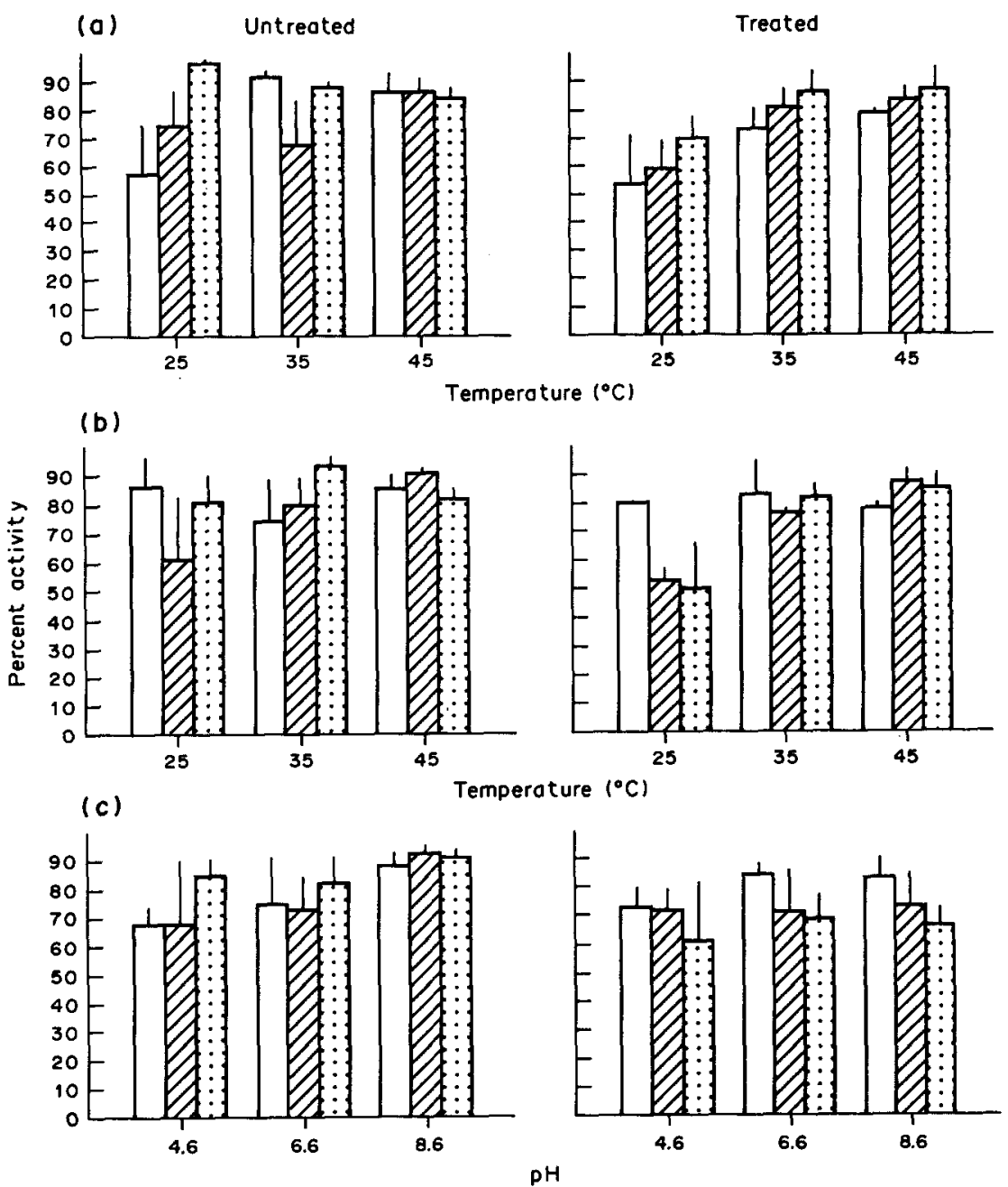

Fig. 3. Percent activity of Vibrio cholerae ATCC 25872 at various $\mathrm{pHs}$ incubated at selected temperatures in untreated and treated rum effluents. [Mean $\pm \mathrm{SE}$ : (a) open bars $=\mathrm{pH} \mathrm{4.6}$; left hatched bars $=\mathrm{pH} \mathrm{6.6}$; dotted bars $=\mathrm{pH} 8.6$; (b) open bars $=25 \%$; left hatched bars $=50 \%$; dotted bars $=100 \%$; (c) open bars $=25 \%$; left hatched bars $=50 \%$; dotted bars $=100 \%$, percent concentration of effluent in filter-sterilized sea water.]

with pH $(F=5.0$, d.f. $=4$ and $24, P<0.005)$ and type of effluent treatment $(F=3.0$, d.f. $=8$ and 24 , $P<0.02)$ caused significant differences in the percentage of respiring cells in the microcosms. Treated effluents had a percentage of respiring cells that was almost $10 \%$ higher than untreated effluents.

\section{Bacterial survival}

Densities of $V$. cholerae, as measured by Coulter Counter decreased significantly over time $(F=3.8$, d.f. $=10$ and $22, P<0.01$ ). No significant differences by treatment were detected (Fig. 5). Total direct cell counts of $V$. cholerae also showed a significant decrease over time $(F=7.0, \quad$ d.f. $=10$ and 22 , $P<0.001$ ) but not by treatment (Fig. 6). However, direct cell counts were more constant in treated effluent, while untreated effluent direct cell count densities decreased sharply. The percentage of active cells decreased significantly over time $(F=3.5$, d.f. $=10$ and $22, P<0.02$ ) but not by treatment level (Fig. 7). There was no significant difference by treatment for percentage of respiring cells of $V$. cholerae (Fig. 8). However, a significant decrease over time was observed $(F=7.7$, d.f $=10$ and $22, P<0.001)$.

\section{DISCUSSION}

Rum distillery effluents have extremely high BOD and COD. These values are not higher than those previously reported for molasses, but are significantly higher than those reported for other types of distillery effluents, such as grains and wine (Sheehan and Greenfield, 1980); and other high organic wastewaters, such as potato-starch, retting and slaughterhouse effluents (La Riviére, 1977). Other limiting nutrients, such as phosphorus and sulfur are also very high in rum distillery effluents (Biamón and Hazen, 1983; Costle, 1979; Gonzalez et al., 1979; López- 

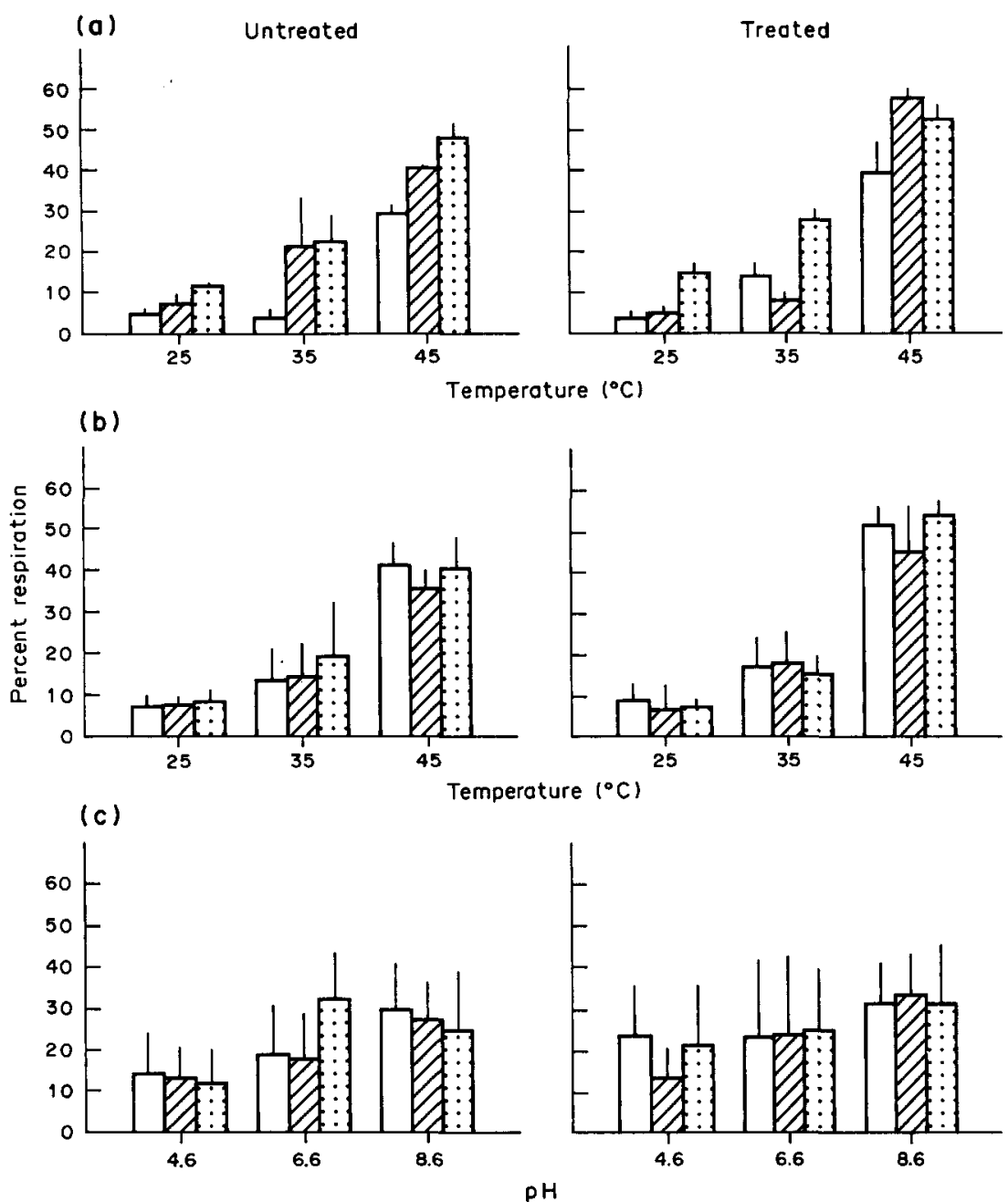

Fig. 4. Percent respiration of Vibrio cholerae ATCC 25872 at various $\mathrm{pHs}$ incubated at selected temperatures in untreated and treated rum effluents. [Mean $\pm \mathrm{SE}$ : (a) open bars $=\mathrm{pH} 4.6$; left hatched bars $=\mathrm{pH} 6.6$; dotted bars $=\mathrm{pH} 8.6$; (b) open bars $=25 \%$; left hatched bars $=50 \%$; dotted bars $=100 \%$; (c) open bars $=25 \%$; left hatched bars $=50 \%$; dotted bars $=100 \%$, percent concentration of effluent in filter-sterilized sea water.]

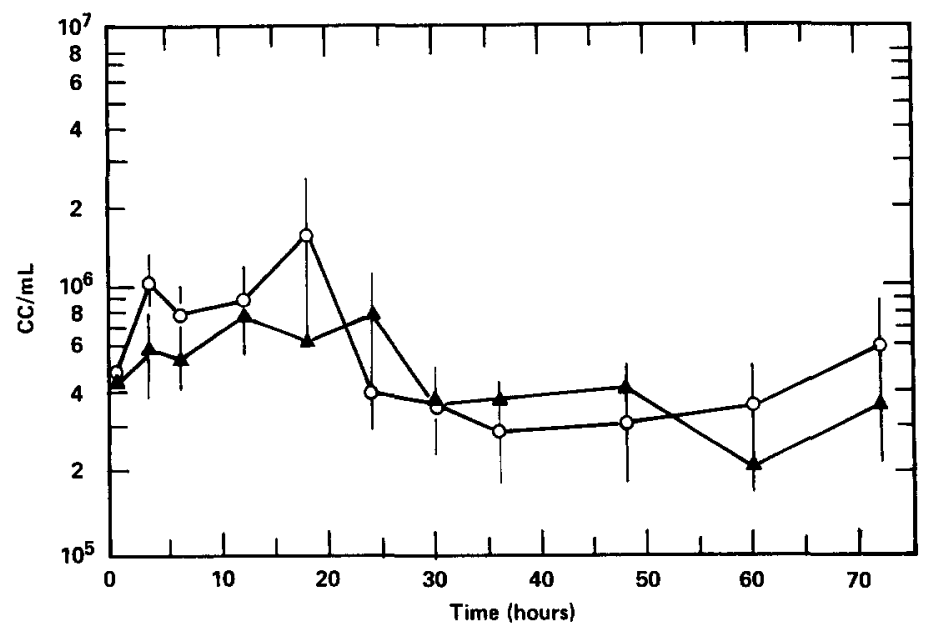

Fig. 5. Survival of Vibrio cholerae ATCC 25872 in rum distillery effluents; Coulter Counter counts. (Mean \pm SE: open circles $=$ untreated effluents; closed triangles $=$ treated effluents.) 


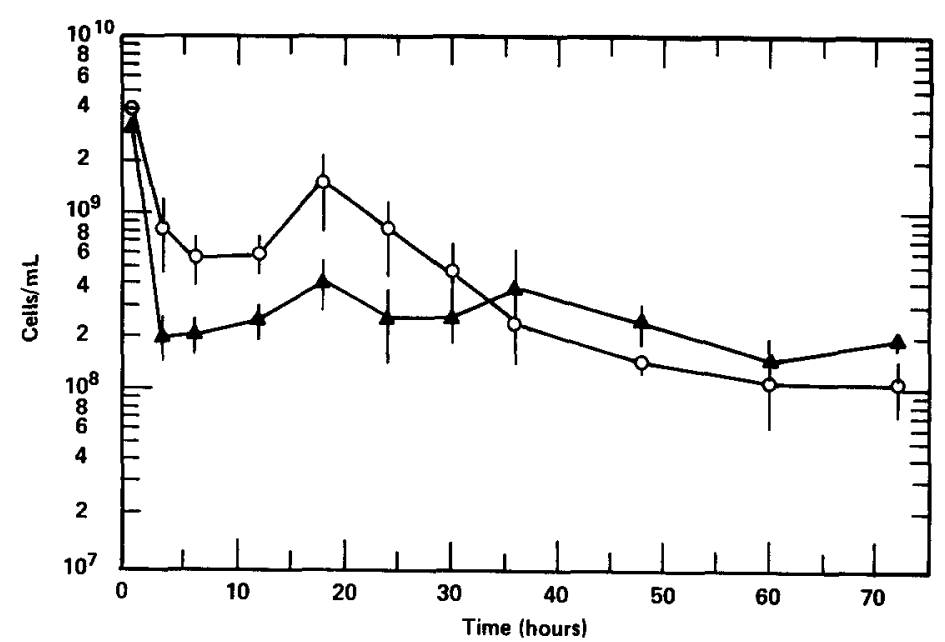

Fig. 6. Survival of Vibrio cholerae ATCC 25872 in rum distillery effluents; total cell counts. (Mean \pm SE: open circles $=$ untreated effluents; closed triangles $=$ treated effluents.)

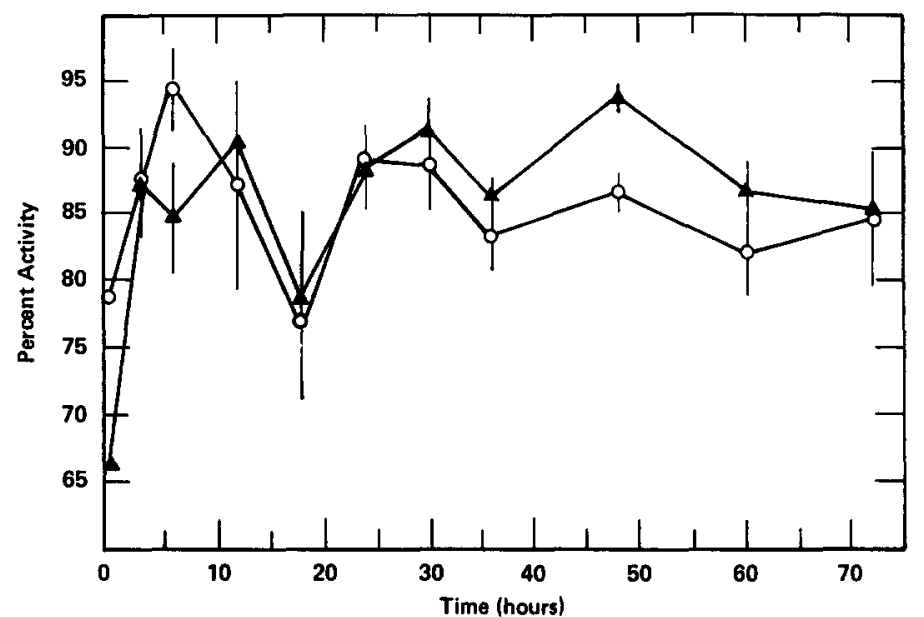

Fig. 7. Survival of Vibrio cholerae ATCC 25872 in rum distillery effluents; percent activity. (Mean \pm SE open circles $=$ untreated effluents; closed triangles = treated effluents.)

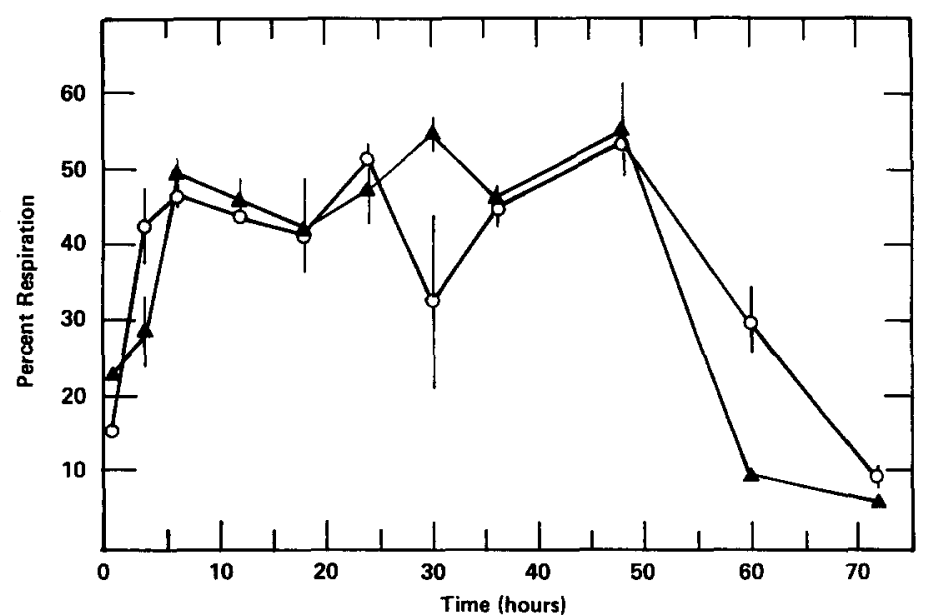

Fig. 8. Survival of Vibrio cholerae ATCC 25872 in rum distillery effluents; percent respiration. $($ Mean \pm SE: open circles $=$ untreated effluents; closed triangles $=$ treated effluents.) 
Torres et al., 1988; Valdés-Collazo et al., 1987). Despite the high nutrient content of this effluent, anaerobic digestion had an undetectable effect on either BOD or COD. This might be explained by the fact that dilution is necessary to overcome inhibition of the digestion process by toxic ions, which can decrease the BOD removal. In fact, BOD removal increases as organic loading of the digestor is decreased (Sheehan and Greenfield, 1980). Despite the apparent lack of effect on BOD and COD, large quantities of methane were produced by the digestor, thus significant organic reduction was occurring, i.e. standard $\mathrm{BOD}_{5}$ measurements were insensitive to the changes that were occurring. This suggests that due to the extremely high $\mathrm{BOD}_{5}$ values recorded (>32,000 $\mathrm{mg} \mathrm{O}_{2}$ day $^{-1}$ ) for rum distillery effluent, the methane digestor used had no apparent effect on $\mathrm{BOD}$ reduction.

It is known that under extreme conditions in $\mathrm{pH}$, temperature and nutrient availability pathogenic bacteria such as $V$. cholerae cannot survive (Roberts and Seidler, 1984). These are also the critical parameters for the proper performance of an anaerobic digestor. However, if these factors are brought to optimal conditions, $V$. cholerae are able to grow. Previous studies have shown that temperature seems to have the greatest effect on the growth of $V$. cholerae. Culturable densities are effected more than direct cell counts, especially at temperatures above $45^{\circ} \mathrm{C}$ and below pH 6.6. However, this was not the case in our microcosm studies with rum effluents. Tiny microcolonies could be observed $24 \mathrm{~h}$ after inoculation in all microcosms at $45^{\circ} \mathrm{C}$ and $\mathrm{pH}$ 6.6. The extremely nutrient rich mostos apparently makes $V$. cholerae reach the highest populations in half the time reported previously for microcosm studies (Singleton et al., 1982a,b).

The effect of distillery treatment with temperature and $\mathrm{pH}$ is diminished on direct cell counts. Moreover, only at $35^{\circ} \mathrm{C}$ is the expected density increase with $\mathrm{pH}$ observed. Extreme temperatures show a similar effect of lowering densities with increasing $\mathrm{pH}$. Cells growing at 25 and $45^{\circ} \mathrm{C}$ at high $\mathrm{pH}$ were coccoid in morphology, with some increase in cell number, indicating a stress status on the populations. Baker et al. (1983) also reported a decrease in cell volume of $V$. cholerae associated with increase in cell number as a survival mechanism to nutrient deprivation. Baker et al. (1983) also argued that these coccoid cells are more resistant to cold temperatures. Thus $V$. cholerae could survive in a nearly dormant stage under suboptimal temperature and nutrient concentrations, waiting for suitable conditions for recovery. The conditions normally present in rum effluents do not allow $V$. cholerae to reach the viable but nonculturable stage found in many stressed bacteria (Colwell et al., 1985). This hypereutrophic environment allows high recovery of injured bacteria in half the time required for most ambient waters.

Activity of $V$. cholerae, in terms of protein syn- thesis decreases with treatment. However, it shows more defined response patterns to environmental factors than untreated rum effluents. Even at extreme temperatures, activity rises with increasing $\mathrm{pH}$. On the other hand, the $\mathrm{pH}$ effect may be masked by the effluent concentration. Sulfate enhances activity, but under anaerobic conditions it could be turned to sulfide which is toxic. Thus the toxic effects of high sulfide concentrations in treated mostos could be responsible for reducing the density and activity enhancing effect of higher $\mathrm{pH}$ seen in untreated effluent. Heterotrophic activity and respiration also decrease in treated effluents. Incorporation of INT is clearly associated with temperature, since $\mathrm{pH}$, as in the percentage activity could be masked by effluent concentration.

Survival of $V$. cholerae in the diffusion chambers did not show significant differences by treatment. Both Coulter Counter cell counts and AODC showed an initial increase in density followed by gradual significant decrease over time. Tosteson and Hale (1979) and Hale and Tosteson (1979) reported that in the presence of distillery effluent, most bacterial cells tend to form aggregates. That could explain the $4 \mathrm{log}$ difference between the Coulter Counter and AODC counts. Bacteria in untreated mostos decreased more rapidly than cells in treated effluents, metabolism followed a similar pattern. This was different from the microcosm survival studies in which treated effluents showed a significant decrease in all density and metabolic parameters. Only the strict control on certain critical parameters of the microecosystems differed in both studies. Thus, diffusion chambers resemble more natural environments. Survival rates were also higher than those reported for $V$. cholerae in ambient waters, even after 3 days in the low $\mathrm{pH}$, high carbohydrate mostos. It was reported by Fuentes et al. (1983) that $V$. cholerae shows a strong positive chemotaxis and ability to oxidize rum effluents, at low concentrations. This is supported in this study by the high percentage of respiring bacteria which decreases only after $48 \mathrm{~h}$. Thus pathogenic bacteria like $V$. cholerae are able not only to grow, but multiply, regardless of the biological treatment used.

This study has shown that the anaerobic digestion treatment fails to control some pathogenic bacterial populations. Methane anaerobic treatment should be considered mainly as an energy recovering method and not as a vehicle for reduction of environmental impact of high organic wastewater effluents. This reduction can be achieved only by more advanced secondary and tertiary treatment systems.

Acknowledgements-We thank Susan Rivera, Francisco Fuentes, Andrés Calvo, William Arias, Inés Muñiz, Jésus Santiago and Luz Rodriguez for their technical assistance. We are especially grateful to Gary A. Toranzos and Carl B. Fliermans who made many helpful suggestions regarding the manuscript. Mariaden Metha, Quality Control Laboratory, College of Engineering, University of Puerto Rico, 
Mayagüez Campus graciously provided treated effluent from his methane digestor during the study. Engineer Lourdes Cruz Candelario from the Puerto Distillers Co., Arecibo supplied the untreated rum effluent samples. This work was supported by the Water Resources Research Institute of the University of Puerto Rico at Mayagüez and in part by Sea Grant R/LR-08-87-THAl and by Public Health Service grants RR-2657 and RR-8102 from the National Institutes of Health. This work was part of the M.Sc. thesis of Y. A. Rojas at the University of Puerto Rico, RTO Piedras, Puerto Rico, 1987.

\section{REFERENCES}

APHA (1985) Standard Method for the Examination of Water and Wastewater, 16th edition. American Public Health Association, Washington, D.C.

Baker R. M., Singleton F. L. and M. A. Hood (1983) Effects of nutrient deprivation on Vibrio cholerae. Appl. envir. Microbiol. 46, 930-940.

Biamón E. J. and Hazen T. C. (1983) Survival and distribution of Aeromonas hydrophila in near-shore coastal waters of Puerto Rico receiving rum distillery effluent. Wat. Res. 17, 319--326.

Carrillo M., Estrada E. and Hazen T. C. (1985) Survival of enumeration of the fecal indicators Bifidobacterium adolescentis and Escherichia coli in a tropical rain forest watershed. Appl. envir. Microbiol. 50, 468-476.

Colwell R. R., Brayton P. R., Grimes D. J., Roszak D. B., Huq S. A. and Palmer L. M. (1985) Viable but nonculturable Vibrio cholerae and related pathogens in the environment: implications for release of genetically engineered microorganisms. BioTechnology 3, 817-820.

Colwell R. R., Seidler R. J., Kaper J., Joseph S. W., Garges S., Lockman H., Maneval D., Bradford H., Roberts N., Remmers E., Huq I. and Huq A. (1981) Occurrence of Vibrio cholerae serotype 0:1 in Maryland and Louisiana estuaries. Appl. envir. Microbiol. 41, 555-558.

Costle D. M. (1979) Effect of distillery wastes on the marine environment. United States Environmental Protection Agency, Washington, D.C.

Davis J. W. and Sizemore R. W. (1982) Incidence of Vibrio species associated with blue crabs (Callinectes sapidus) collected from Galveston Bay, Texas. Appl. envir. Microbiol. 43, 1092-1097.

Desmarchelier P. M. and Reichelt J. L. (1981) Phenotypic characterization of clinical and environmental isolates of Vibrio cholerae from Australia. Curr. Microbiol. 5, $127-130$.

Desmarchelier P. M. and Reichelt J. L. (1982) Genetic relationships among clinical and environmental isolates of Vibrio cholerae from Australia. Curr. Microbiol. 7, 53-57.

Fuentes F. A., Biamón E. J. and Hazen T. C. (1983) Bacterial chemotaxis to effluent from a rum distillery in tropical near-shore coastal waters. Appl. envir. Microbiol. 46, 1438-1441.

Fujioka R. S., Hashimoto H. H., Siwak E. B. and Young R. H. (1981) Effect of sunlight on survival of indicator bacteria in seawater. Appl. envir. Microbiol. 41, 690-696.

Gonzalez J. G., Yoshioka P. M., Zimmermann R. J., López J. M., Hernandez-Avila M., Suhayda J. N., Roberts H. H., Cruz Baez D., Pesante D. and Velazco A. T. (1979) Biological effects of rum slops in the marine environment United States Environmental Protection Agency, Washington, D.C.

Grimes D. J., Singleton F. L., Stemmler J., Palmer L. M., Brayton P. and Colwell R. R. (1984) Microbiological effects of wastewater effluent discharge into coastal waters of Puerto Rico. Wat. Res. 18, 613-619.

Guthrie R. K. and Scovill M. A. (1984) Recovery of Escherichia coli and Vibrio cholerae from aquatic microcosms. Wat. Res. 18, 1055-1057.
Hagler A. N. and Medonça-Hagler L. C. (1981) Yeasts from marine and estuarine waters with different levels of pollution in the state of Río de Janeiro, Brazil. Appl. envir. Microbiol. 41, 173-178.

Hale D. R. and Tosteson T. R. (1979) The utilization of rum slops by marine bacteria. II. Characterization of efficient strains. J. argic. Univ. Puerto Rico LXIII, 189-194.

Hazen T. C., Santiago-Mercado J., Toranzos G. A. and Bermúdez M. (1987) What do water fecal coliforms indicate in Puerto Rico? A review. Bull. Puerto Rico med. Ass. 79, 189-193.

Hood M. A. and Ness G. E. (1982) Survival of Vibrio cholerae and Escherichia coli in estuarine waters and sediments. Appl. envir. Microbiol. 43, 578-584.

Hood M. A., Guckert J. B., White D. C. and Deck F. (1986) Effect of nutrient deprivation on lipid, carbohydrate, DNA, RNA, and protein levels in Vibrio cholerae. Appl. envir. Microbiol. 52, 788-793.

Hood M. A., Ness G. E., Rodrick G. E. and Blake N. J. (1983) Distribution of Vibrio cholerae in two Florida estuaries. Microb. Ecol. 9, 65-75.

Huq A., West P. A., Small E. B., Huq M. I. and Colwell R. R. (1984) Influence of water temperature, salinity, and $\mathrm{pH}$ on survival and growth of toxigenic Vibrio cholerae serovar $0: 1$ associated with live copepods in laboratory microcosms. Appl. envir. Microbiol. 48, 420-424.

Kaper J., Lockman H., Colwell R. R. and Joseph S. W. (1979) Ecology, serology, and enterotoxin production of Vibrio cholerae in Chesapeake Bay. Appl envir. Microbiol. 37, 91-103.

Kenyon J. E., Piexoto D. R., Austin B. and Gillies D. C. (1984) Seasonal variation in numbers of Vibrio cholerae (non-01) isolated from California coastal waters. Appl. envir. Microbiol. 47, 1243-1245.

Kodama H., Gyobu Y., Tokuman N., Okada I., Uetake H., Shimada T. and Sakazaki R. (1984) Ecology of non-01 Vibrio cholerae in Toyama Prefecture. Microbiol. Immun. 28, 311-325.

La Riviére J. W. M. (1977) Microbial ecology of liquid waste treatment. Adv. microb. Ecol. 1, 215-259.

Lee J. V., Bashford D. J., Donovan T. J., Furniss A. L. and West P. A. (1982) The incidence of Vibrio cholerae in water, animals and birds in Kent, England. J. appl. Bact. 52, 281-291.

López-Torres A. J., Hazen T. C. and Toranzos G. A. (1987) Distribution and in situ survival and activity of Klebsiella pneumoniae in a tropical rain forest watershed. Curr. Microbiol. 15, 213-218.

López-Torres A. J., Prieto L. and Hazen T. C. (1988) Comparison of the in situ survival and activity of Klebsiella pneumoniae and Escherichia coli in tropical marine environments. Microb. Ecol. 15, 41-57.

McFeters G. A. and Stuart D. G. (1972) Survival of coliform bacteria in natural waters: field and laboratory studies with membrane filter chambers. Appl. Microbiol. 24, 805-811.

Motes M. L., Zywno S. R., DePaola A., Becker R. E. and Presnell M. W. (1983) Isolation of Vibrio cholerae serotype Ogawa from a Florida estuary. Appl. envir. Microbiol. 45, 321-322.

Roberts N. C. and Seidler R. J. (1984) Methods for monitoring vibrios in the environment. In In the Environment (Edited by Colwell R. R.), pp. 269-275. Wiley, New York.

Roberts N. C., Siebeling R. J., Kaper J. B. and Bradford H. B. Jr (1982) Vibrios in the Louisiana Gulf Coast environment. Microb. Ecol. 8, 299-312.

Rogers R. C., Cuffe C. J., Cossins Y. M., Murphy D. M. and Bourke A. T. C. (1980) The Queensland cholera incident of 1977. 2. The epidemiological investigation. Bull. Wld Hith Org. 58, 665-669.

Seidler R. J. and Evans T. M. (1984) Computer-assisted analysis of Vibrio field data: four coastal areas. In Vibrios 
in the Environment (Edited by Colwell R. R.), pp. 411-426. Wiley, New York.

Sheehan G. J. and Greenfield P. F. (1980) Utilization, treatment and disposal of distillery waste water. Wat. Res. 14, 257-277.

Singleton F. L., Atwell R. W., Jangi M. S. and Colwell R. R. (1982a) Influence of salinity and organic nutrient concentration on survival and growth of Vibrio cholerae in aquatic microcosms. Appl. envir. Microbiol. 43, 1080-1085.

Singleton F. L., Atwell R. W., Jangi M. S. and Colwell R. R. (1982b) Effects of temperature and salinity on Vibrio cholerae growth. Appl. envir. Microbiol. 44, 1047-1058.

Spira W. W., Huq A., Ahmed Q. S. and Saeed Y. A. (1981) Uptake of Vibrio cholerae Biotype eltor from contaminated water by water hyacinth (Eichornia crassipes). Appl. envir. Microbiol. 42, 550-553.

Tosteson T. R. and Hale D. R. (1979) The utilization of rum slops by marine bacteria. I. Isolation of efficient strains. J. agric. Univ. Puerto Rico LXIII, 180-188.
Valdés-Collazo L., Schultz A. J. and Hazen T. C. (1987) Survival of Candida albicans in tropical marine and freshwaters. Appl. envir. Microbiol. 53, 1762-1767.

Vasconcelos G. J. and Swartz R. G. (1976) Survival of bacteria in seawater using a diffusion chamber apparatus in situ. Appl. envir. Microbiol. 31, 913-920.

West P. A. and Lee J. V. (1982) Ecology of Vibrio species, including Vibrio cholerae in natural waters of Kent, England. J. appl. Bact. 52, 435-448.

Xu H., Roberts N., Singleton F. L., Atwell R. W., Grimes D. J. and Colwell R. R. (1982) Survival and viability of nonculturable Escherichia coli and Vibrio cholerae in the estuarine and marine environment. Microb. Ecol. 8, 313-323.

Zar J. H. (1984) Biostatistical Analysis, 2nd edition. Prentice-Hall, Englewood Cliffs, N.J.

Zimmermann R. R., Iturriaga R and Becker-Birck J. (1978) Simultaneous determination of the total number of aquatic bacteria and the number thereof involved in respiration. Appl. envir. Microbiol. 36, 926-935. 